\title{
Influence of the Acyl Moiety on the Hydrolysis of Quinuclidinium Esters Catalyzed by Butyrylcholinesterase ${ }^{\dagger}$
}

\author{
Ines Primožičc* and Srđanka Tomić \\ Department of Chemistry, Faculty of Science, University of Zagreb Horvatovac 102a, HR-10000 Zagreb, Croatia \\ RECEIVED APRIL 15, 2011; REVISED JULY 1, 2011; ACCEPTED JULY 6, 2011

\begin{abstract}
Eight chiral esters of quinuclidin-3-ol and butyric, acetic, pivalic and benzoic acid were synthesized as well as their racemic and chiral, quaternary $N$-benzyl derivatives. All racemic and chiral quaternary compounds were studied as substrates and/or inhibitors of horse serum butyrylcholinesterase (BChE). The best substrate for the enzyme was $(R)$ - $N$-benzyl butyrate. The rates of hydrolysis decreased in order $(R)$-butyrate $>>(R)$-acetate (7-fold slower) $>(R)$-pivalate (8-fold slower) $>(R)$-benzoate (9-fold slower reaction), while $(S)$ - $N$-benzyl esters were much poorer substrates (320 (butyrate) - 4360-fold slower (pivalate) than the appropriate $(R)$-enantiomer). For all $(S)$ - $N$-benzyl esters excluding $(S)$ - $N$-benzyl acetate inhibition constants were determined $\left(K_{\mathrm{a}}=3.3-60 \mu \mathrm{mol} \mathrm{dm}{ }^{-3}\right)$. The hydrolysis of racemic mixtures of $N$-benzyl esters proceeded 1.4 (for acetate) -5.1 (for benzoate) times slower than that of pure $(R)$ enantiomers of the corresponding concentrations due to the inhibition with $(S)$-enantiomers. Change of the acyl moiety of the substrate effected both activity and stereoselectivity of the BChE.(doi: $10.5562 /$ cca1829)
\end{abstract}

Keywords: esters of quinuclidin-3-ol, enzymic resolution, butyrylcholinesterase, hydrolysis kinetics, inhibition constants

\section{INTRODUCTION}

Azabicyclo[2.2.2]octan-3-ol, its derivatives and other quinuclidine compounds display a broad range of biological activities and pharmaceutical industries have large interest to explore them. ${ }^{1}$ Among other activities, they were shown to be potential antidotes against organophosphorus poisoning caused by warfare agents. ${ }^{2-4}$ Quinuclidin-3-ol is a chiral compound which contains an asymmetric carbon atom at the position 3 of the bicyclic ring. Since the racemates are regarded with suspicion as pharmaceuticals (enantiomers can have different activity or even toxic effects), the issue of quinuclidin-3-ol resolution has been addressed by using a number of chemi$\mathrm{cal}^{5-7}$ and biocatalytic ${ }^{8,9}$ methods. One of the enzymes tested as a biocatalyst was butyrylcholinesterase from horse serum (BChE, EC 3.1.1.8.). This enzyme has not been used as much as some other esterases for biotransformations in organic chemistry ${ }^{10}$ because of its preference toward positively charged substrates which resemble its best substrate: butyryl choline. ${ }^{11-13}$ Structural similarity among choline and quinuclidin-3-ol implied that quinuclidine esters might be good substrates of the enzyme. Thus, it was possible to use $\mathrm{BChE}$ for the reso- lution of racemic nonquaternized quinuclidin-3-yl butyrate $^{8}$ and for the hydrolysis of $(R)$ - and $(S)$-quinuclidin3 -yl benzoates, ${ }^{14-16}$ stereoselectivity of hydrolyses being in favour of the $(R)$-enantiomer.

In this paper the synthesis of quaternary, $N$-benzyl derivatives of racemic, $(R)$ - and $(S)$-quinuclidin-3-yl butyrate, acetate, pivalate and benzoate are reported, Figure 1. Quaternization with $N$-benzyl group was used because it can be considered as a protecting group which can be successfully removed afterwards. ${ }^{17}$

All synthesized quaternary compounds were studied as substrates and/or inhibitors of horse serum $\mathrm{BChE}$ to determine the potential of $\mathrm{BChE}$ as a biocatalyst in kinetic resolution of quinuclidine esters.
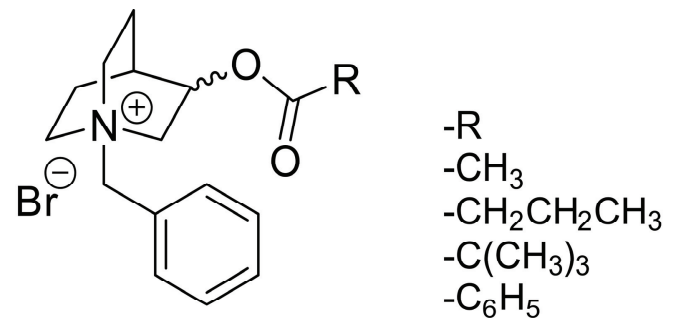

AcBzl $\mathrm{BuBzl}$ PivBz $\mathrm{BzBz}$

Figure 1. Structures of synthesized quinuclidinium esters.

\footnotetext{
$\dagger$ This article belongs to the Special Issue Chemistry of Living Systems devoted to the intersection of chemistry with life.

* Author to whom correspondence should be addressed. (E-mail: ines.primozic@chem.pmf.hr)
} 


\section{EXPERIMENTAL SECTION}

Melting points were determined in open capillaries using a Büchi B-540 melting point apparatus and are uncorrected. Specific optical rotation values were determined with an Optical Activity LTD automatic polarimeter AA-10 on $589 \mathrm{~nm}$ at ambient temperature $(\approx 24$ $\left.{ }^{\circ} \mathrm{C}\right)$ in methanol. Elemental analyses were performed with a Perkin-Elmer PE 2400 Series II CHNS/O Analyser. IR spectra were recorded with a Perkin-Elmer FTIR $1725 \mathrm{X}$ spectrometer. ${ }^{1} \mathrm{H}$ and ${ }^{13} \mathrm{C} 1 \mathrm{D}$ and $2 \mathrm{D}$ NMR spectra were recorded with Varian XL-GEM 300 spectrometer at room temperature. Chemical shifts are given in ppm downfield from TMS as internal standard. HPLC analyses (Thermo Separation Products, SpectraSYSTEM 2000) were performed on a RP18 (Waters, SymmetryShield, $5 \mu \mathrm{m}, 3.9 \times 150 \mathrm{~mm})$ column $\left(40{ }^{\circ} \mathrm{C}\right)$. The mobile phase used was water/ methanol/ acetonitrile/ acetic acid/ triethylamine (60/25/15/0.33/0.2), flow rate $1 \mathrm{ml} / \mathrm{min}$. The reactions were carried out in Heidolph UNIMAX 1100 Shaker. BChE (EC 3.1.1.8), type IV-S lyophilized powder from horse serum (Sigma Chemical Co.) was used without further purification. The hydrolysis of esters catalyzed by $\mathrm{BChE}$ was monitored by following the production of $N$-benzylquinuclidin-3-ol by HPLC analysis as described previously. ${ }^{15}$ All experiments for $(R)$-enantiomers were performed with $1.5 \times 10^{-9} \mathrm{~mol} \mathrm{dm}{ }^{-3}$ and for $(S)$-enantiomers with $1.5 \times 10^{-8} \mathrm{~mol} \mathrm{dm}^{-3}$ concentration of BChE. The dissociation constants of enzyme-inhibitor complex for ( $S$ )-enantiomers were determined from Hunter-Downs plot, using benzoyl choline (BzCh) as a substrate.

\section{Preparation of substrates}

$(R)$ - and $(S)$ - quinuclidin-3-ol were prepared by a resolution procedure as described previously using L- and D-tartaric acid. ${ }^{5}$ All esters were prepared according to the procedure described for quinuclidin-3-yl benzoate. ${ }^{14}$ $N$-quaternary derivatives were prepared by the addition of benzyl bromide (2 equivalents) to the solution of appropriate chiral quinuclidin-3yl ester in dry ether. Synthesis and physical properties of benzoates $(\mathrm{BzBzl})^{15}$ and acetates $(\mathrm{AcBzl})^{18}$ were described previously.

Quinuclidin-3-yl butyrate, colourless oil, yield $95 \%$, $(R)$-enantiomer: $[\alpha]_{\mathrm{D}}^{23}-22.0^{\circ}(c=3, \mathrm{EtOH}),(S)$-enantiomer $[\alpha]_{\mathrm{D}}^{23}+22.0^{\circ}\left(c=3\right.$, EtOH); IR $(\mathrm{NaCl}) \tilde{v} / \mathrm{cm}^{-1}$ : 2948, 2873, 1731 1457, 1310,1257, 1185, 1081, 979, 779, 753; ${ }^{1} \mathbf{H}$ NMR $\left(\mathrm{CDCl}_{3}\right) \delta / \mathrm{ppm}: 0.93\left(\mathrm{t}, 3 \mathrm{H},-{ }^{-} \mathrm{CH}_{3}\right.$, $\left.{ }^{3} J=7.4 \mathrm{~Hz}\right), 1.35-1.95\left(\mathrm{~m}, 6 \mathrm{H}, \mathrm{H}_{5}, \mathrm{H}_{8}\right.$ and $\left.-\mathrm{CH}_{2} \mathrm{CH}_{3}\right)$, 1.95-2.01 (m, 1H, $\left.\mathrm{H}_{4}\right), 2.27\left(\mathrm{t}, 2 \mathrm{H},-\mathrm{CH}_{2} \mathrm{CH}_{2} \mathrm{CH}_{3},{ }^{3} \mathrm{~J}=\right.$ 7,4 Hz), $2.62-2.90\left(\mathrm{~m}, 5 \mathrm{H}, \mathrm{H}_{6}, \mathrm{H}_{7}\right.$ and $1 \mathrm{H}_{2}$ cis $), 3.21$ (dd, $1 \mathrm{H}, \mathrm{H}_{2},{ }^{2} J=14.6$ and $^{3} J=8.5 \mathrm{~Hz}$, trans), $4.66-4.81$ $\left(\mathrm{m}, 1 \mathrm{H}, \mathrm{H}_{3}\right) ;{ }^{13} \mathbf{C}$ NMR $\left(\mathrm{CDCl}_{3}\right) \delta / \mathrm{ppm}: 13.41\left(-\mathrm{CH}_{3}\right)$, $18.27\left(\mathrm{C}_{8}\right), 19.20\left(\mathrm{C}_{5}\right), 24.15\left(-\mathrm{CH}_{2} \mathrm{CH}_{2} \mathrm{CH}_{3}\right), 24.91$ $\left(\mathrm{C}_{4}\right), 36.20\left(-\mathrm{CH}_{2} \mathrm{CH}_{2} \mathrm{CH}_{3}\right), 46.16\left(\mathrm{C}_{6}\right), 47.07\left(\mathrm{C}_{7}\right)$, $55.20\left(\mathrm{C}_{2}\right), 70.62\left(\mathrm{C}_{3}\right), 173.47(\mathrm{C}=\mathrm{O})$; ESMS: $\mathrm{m} / \mathrm{z}(\mathrm{m} / \mathrm{z}$ calcd. for $\mathrm{C}_{11} \mathrm{H}_{20} \mathrm{NO}_{2}^{+}, 198.14$ ) found 198.2.

\section{3-Butyryloxy-1-benzylquinuclidinium bromide}

(BuBzl): recrystallization from methanol/ether gave white crystals, yield $94 \%$; m.p. $169.1-170.0{ }^{\circ} \mathrm{C}$ (decomp.); $(R)$-enantiomer (RBuBzl): $[\alpha]_{\mathrm{D}}^{23}+19.0^{\circ}(c=1$, EtOH); $(S)$-enantiomer (SBuBzl): $[\alpha]_{\mathrm{D}}^{23}-19.0^{\circ}(c=1$, $\mathrm{EtOH}) ; \mathbf{U V}(\mathrm{EtOH}) \lambda_{\max } / \mathrm{nm}: 257,262$ and $269(\log \varepsilon /$ $\mathrm{dm}^{3} \mathrm{~mol}^{-1} \mathrm{~cm}^{-1}: 2.50 ; 2.55$ and 2.42); IR (KBr) $\tilde{v} / \mathrm{cm}^{-1}$ : $3022,2955,2877,1726,1461,1453,1378,1283,1156$, 1002, 980, 706; ${ }^{1} \mathbf{H}$ NMR $\left(\mathrm{CDCl}_{3}\right) \delta / \mathrm{ppm}: 0.86(\mathrm{t}, 3 \mathrm{H}$, $\left.-\mathrm{CH}_{3},{ }^{3} \mathrm{~J}=7,4 \mathrm{~Hz}\right), 1.50-1.65\left(\mathrm{~m}, 2 \mathrm{H},-\mathrm{CH}_{2} \mathrm{CH}_{3}\right)$, 1.87-2.49 (m, 5H, $\mathrm{H}_{5}, \mathrm{H}_{8}$ and $\left.\mathrm{H}_{4}\right), 2,34(\mathrm{t}, 2 \mathrm{H}$, - $\left.\mathrm{CH}_{2} \mathrm{CH}_{2} \mathrm{CH}_{3},{ }^{3} \mathrm{~J}=7,4 \mathrm{~Hz}\right), 3.31-4.02\left(\mathrm{~m}, 5 \mathrm{H}, \mathrm{H}_{6}, \mathrm{H}_{7}\right.$ and $1 \mathrm{H}_{2}$ cis $), 4.20-4.40\left(\mathrm{~m}, 1 \mathrm{H}, \mathrm{H}_{2}\right.$ trans $), 5.05-5.21$ (m, 3H, $-\mathrm{C}_{2}-b z l$ and $\left.\mathrm{H}_{3}\right), 7.25-7.71(\mathrm{~m}, 5 \mathrm{H}, b z l) ;{ }^{13} \mathbf{C}$ NMR $\left(\mathrm{CDCl}_{3}\right) \delta /$ ppm: $13.38\left(-\mathrm{CH}_{3}\right), 17.99\left(\mathrm{C}_{8}\right), 18.21$

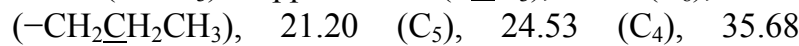
$\left(-\mathrm{CH}_{2} \mathrm{CH}_{2} \mathrm{CH}_{3}\right), 53.23\left(\mathrm{C}_{6}\right), 53.64\left(\mathrm{C}_{7}\right), 59.74\left(\mathrm{C}_{2}\right)$, $66.31\left(-\mathrm{CH}_{2}-b z l\right), 66.69\left(\mathrm{C}_{3}\right), 126.59\left(\mathrm{C}_{1} b z l\right), 129.00$ $\left(\mathrm{C}_{3}, \mathrm{C}_{5} b z l\right), 130.34\left(\mathrm{C}_{4} b z l\right), 133.18\left(\mathrm{C}_{2}, \mathrm{C}_{6} b z l\right), 172.56$ $(\mathrm{C}=\mathrm{O})$; ESMS: $m / z$ (calcd. for $\mathrm{C}_{12} \mathrm{H}_{22} \mathrm{NO}_{2}{ }^{+}$288.20) found 288.3.

Anal. Calcd. mass fractions of elements, $w / \%$, for $\mathrm{C}_{18} \mathrm{H}_{26} \mathrm{BrNO}_{2}\left(M_{\mathrm{r}}=368.31\right)$ are $\mathrm{C} 58.70, \mathrm{H} 7.12, \mathrm{~N}$ 3.80; found: C 57.21; H 7.03; N 3.89.

Quinuclidin-3-yl pivalate, colourless oil, yield $97 \%$, $(R)$-enantiomer: $[\alpha]_{\mathrm{D}}^{27}+18.4^{\circ} \quad(c=2.0 ; \quad \mathrm{EtOH}) ; \quad(S)$ enantiomer $[\alpha]_{\mathrm{D}}^{27}-17.9^{\circ}(c=2.0, \mathrm{EtOH}) ; \mathbf{I R}(\mathrm{NaCl}) \tilde{v}$ $/ \mathrm{cm}^{-1}: 2954,2871,1725,1668,1480,1457,1396,1285$, 1163, 1033, 981, 773; ${ }^{1} \mathbf{H}$ NMR (DMSO-d $\left.{ }_{6}\right) \delta /$ ppm: $1.19\left(\mathrm{~s}, 9 \mathrm{H},\left(\mathrm{C}_{3}\right)_{3} \mathrm{C}\right), 1.31-1.77\left(\mathrm{~m}, 4 \mathrm{H}, \mathrm{H}_{5}\right.$ and $\left.\mathrm{H}_{8}\right)$, 1.85-1.92 (m, $\left.1 \mathrm{H}, \mathrm{H}_{4}\right), 2.38-2.76\left(\mathrm{~m}, 5 \mathrm{H}, \mathrm{H}_{6}, \mathrm{H}_{7}\right.$ and $\mathrm{H}_{2}$ cis), 3.09 (dd, $1 \mathrm{H}, \mathrm{H}_{2},{ }^{2} J=14.5 \mathrm{i}^{3} J=8.2 \mathrm{~Hz}$, trans), 4.60-4.67 (m, $\left.1 \mathrm{H}, \mathrm{H}_{3}\right) ;{ }^{13} \mathbf{C}$ NMR (DMSO-d $\left.{ }_{6}\right) \delta / \mathrm{ppm}$ : $19.41\left(\mathrm{C}_{5}\right), 24.05\left(\mathrm{C}_{8}\right), 24.98\left(\mathrm{C}_{4}\right), 26.91\left(\left(\mathrm{CH}_{3}\right)_{3} \mathrm{C}\right)$, $38.28\left(\underline{\mathrm{C}}\left(\mathrm{CH}_{3}\right)_{3}\right), 45.94\left(\mathrm{C}_{6}\right), 46.97\left(\mathrm{C}_{7}\right), 55.30\left(\mathrm{C}_{2}\right)$, $70.71\left(\mathrm{C}_{3}\right), 177.46(\mathrm{C}=\mathrm{O})$; ESMS: $\mathrm{m} / \mathrm{z}$ (calcd. for $\mathrm{C}_{12} \mathrm{H}_{22} \mathrm{NO}_{2}^{+}$212.16) found 212.2.

\section{3-Pivaloyloxy-1-benzylquinuclidinium bromide}

(PivBzl): recrystallization from methanol/ether gave white crystals, yield $86 \%$; m.p. 166.4-167.4 ${ }^{\circ}$; $(R)$ enantiomer (RPivBzl): $[\alpha]_{\mathrm{D}}^{28}-15.0^{\circ}(c=1.0, \mathrm{MeOH})$; $(S)$-enantiomer (SPivBzl): $[\alpha]_{\mathrm{D}}^{28}+15.2^{\circ}(c=1.0, \mathrm{MeOH})$; UV (EtOH) $\lambda_{\max } / \mathrm{nm}: 257,262$ and $269\left(\log \varepsilon / \mathrm{dm}^{3} \mathrm{~mol}^{-1}\right.$ $\mathrm{cm}^{-1}: 2.50 ; 2.55$ and 2.42$)$; IR $(\mathrm{KBr}) \tilde{v} / \mathrm{cm}^{-1}: 3032$, 2955, 2877, 1729, 1465, 1455, 1376, 1284, 1157, 1005, 990, 704; ${ }^{1} \mathbf{H}$ NMR (DMSO-d 6 ) $\delta /$ ppm: 1.19 (s, 9H, $\left.\left(\mathrm{C}_{3}\right)_{3} \mathrm{C}-\right), 1.81-2.08\left(\mathrm{~m}, 4 \mathrm{H}, \mathrm{H}_{5}, \mathrm{H}_{8}\right), 2.27-2.28(\mathrm{~m}$, $\left.1 \mathrm{H}, \mathrm{H}_{4}\right), 3.42-3.56\left(\mathrm{~m}, 5 \mathrm{H}, \mathrm{H}_{6}, \mathrm{H}_{7}, 1 \mathrm{H}_{2}\right.$ cis), 3.87 (dd, $1 \mathrm{H}, \mathrm{H}_{2},{ }^{2} J=12.9$ and ${ }^{3} J=8.7 \mathrm{~Hz}$, trans $), 4.61-4.72(\mathrm{~m}$, 

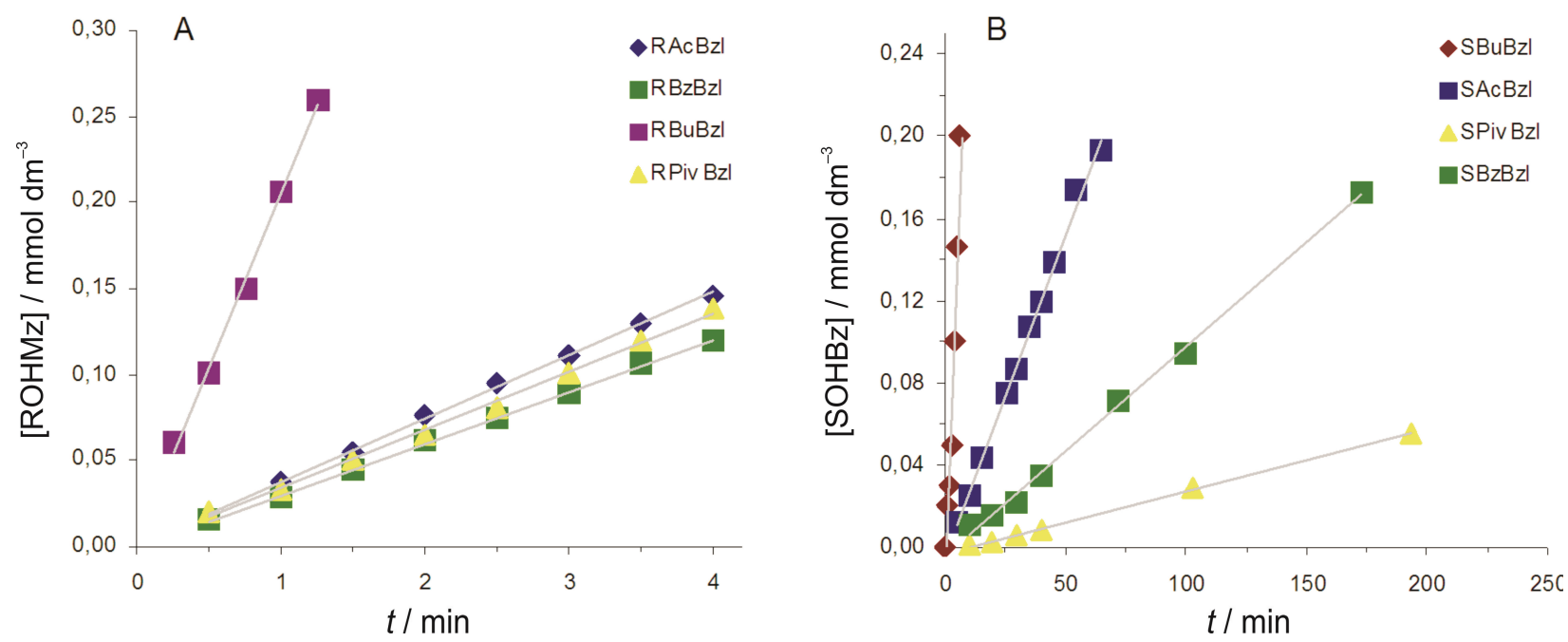

Figure 2. The initial rates of $\mathrm{BChE}$ catalyzed hydrolysis of $\mathrm{A})(R)$-esters $\left(A(\mathrm{BChE}) / \mu \mathrm{mol} \mathrm{dm} \mathrm{min}^{-1} \mathrm{mg}^{-1}\right.$ equals 2069 for

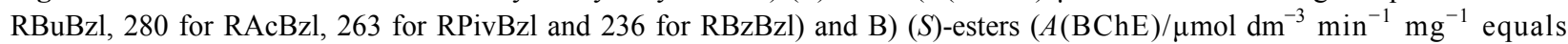
6.480 for SBuBzl, 0.625 for SAcBzl, 0.063 for SPivBzl and 0.203 for SBzBzl). Monitoring was done by the HPLC analysis of the products. Concentration of all substrates was $4 \mathrm{mmol} \mathrm{dm}^{-3}$. Each data point represents the average value of three measurements.

$\left.2 \mathrm{H},-\underline{\mathrm{C}}_{2}-b z l\right), 4.99-5.00\left(\mathrm{~m}, 1 \mathrm{H}, \mathrm{H}_{3}\right), 7.50-7.59(\mathrm{~m}$, $5 \mathrm{H}, b z \bar{l}) ;{ }^{13} \mathrm{C}$ NMR (DMSO-d $\left.{ }_{6}\right) \delta / \mathrm{ppm}: 18.08\left(\mathrm{C}_{5}\right)$, $20.49 \quad\left(\mathrm{C}_{8}\right), \quad 24.20 \quad\left(\mathrm{C}_{4}\right), \quad 26.79 \quad\left(\left(\underline{\mathrm{CH}}_{3}\right)_{3} \mathrm{C}-\right), \quad 38.28$ $\left(\left(\mathrm{CH}_{3}\right)_{3} \mathrm{C}-\right), 52.10\left(\mathrm{C}_{6}\right), 53.80\left(\mathrm{C}_{7}\right), 59.83\left(\mathrm{C}_{2}\right), 65.64$ $\left(-\mathrm{CH}_{2}-b z l\right), 67.07\left(\mathrm{C}_{3}\right), 127.70\left(\mathrm{C}_{1} b z l\right), 129.00\left(\mathrm{C}_{3}, \mathrm{C}_{5}\right.$ $b z l), 130.24\left(\mathrm{C}_{4} b z l\right), 133.21\left(\mathrm{C}_{2}, \mathrm{C}_{6} b z l\right), 176.91(\mathrm{C}=\mathrm{O})$; ESMS: $m / z$ (calcd. for $\mathrm{C}_{19} \mathrm{H}_{28} \mathrm{NO}_{2}{ }^{+} 302.21$ ) found 302.2.

Anal. Calcd. mass fractions of elements, $w / \%$, for $\mathrm{C}_{19} \mathrm{H}_{28} \mathrm{BrNO}_{2}\left(M_{\mathrm{r}}=382.34\right)$ are $\mathrm{C} 59.69, \mathrm{H} 7.38, \mathrm{~N}$ 3.66; found: C 60.38, H 7.12, N 3.59.

\section{RESULTS AND DISCUSSION}

\section{Synthesis of quaternary quinuclidinium esters}

Chiral $(R)$ - and $(S)$-quinuclidin-3-ols were obtained by the resolution of racemic quinuclidin-3-yl acetates with L- and D-tartaric acid. ${ }^{5} N$-benzyl derivatives of racemic, $(R)$ - and (S)-quinuclidin-3-yl acetates, benzoates, pivalates and butyrates were synthesized by the esterification of quinuclidin-3-ol with appropriate anhydride in good yields. Quaternization of racemic and chiral esters with benzyl bromide followed. The structure and purity of all compounds were determined by HPLC, IR, MS, elemental analyses, one- and two-dimensional ${ }^{1} \mathrm{H}$ and ${ }^{13} \mathrm{C}$ NMR.

\section{Hydrolyses of quaternary esters with BchE}

The overall catalytic process of BChE proceeds in three steps: initial formation of an enzyme-substrate complex, an acylation step, and deacylation by hydrolysis, ${ }^{19}$ Scheme 1. In the reaction sequence, E, S, ES, and EA represent free enzyme, substrate, Michaelis complex and acyl-enzyme intermediate, respectively. $\mathrm{P}^{1}$ (alcohol) and $\mathrm{P}^{2}$ (acid) are products of the hydrolysis. In the case of tested quinuclidinium esters, 1-benzyl-3hydroxyquinuclidinium is $\mathrm{P} 1$ and $\mathrm{P} 2$ are acetic, pivalic butyric and benzoic acid respectively.

All tested chiral esters were substrates of the $\mathrm{BChE}$, Figure 2. Analyses of the initial rates revealed that the hydrolysis of butyric esters was the fastest among all examined enantiomers, and that in general the $(R)$-enantiomers are significantly better substrates for BChE then $(S)$-enantiomers. The rates of hydrolysis for $(R)$-enantiomers decreased in order $(R)$-butyrate $>>(R)$ acetate $(7$-fold slower) $>(R)$-pivalate $(8$-fold slower) $>$ $(R)$-benzoate (9-fold slower reaction). The enzyme was even more selective in case of $(S)$-enantiomers: the rates of hydrolysis decreased in order $(S)$-butyrate $>(S)$ acetate $(10$-fold slower) $>(S)$-benzoate (32-fold slower) $>(S)$-pivalate (103-fold slower), Figure 2, chart B. On the other hand, difference in the initial rates for each pair of enantiomers was the biggest for pivalates $\left(A_{\mathrm{R} / \mathrm{S}}=4360\right)$, then benzoates $\left(A_{\mathrm{R} / \mathrm{S}}=1180\right)$, acetates $\left(A_{\mathrm{R} / \mathrm{S}}=450\right)$ and butyrates $\left(A_{\mathrm{R} / \mathrm{S}}=320\right)$.

\section{Inhibition of BChE by (S)-enantiomers}

Since the rates of hydrolysis of $(S)$-enantiomers were much slower than the rate of hydrolysis of benzoyl choline $(\mathrm{BzCh})$ which can be used to monitor enzyme

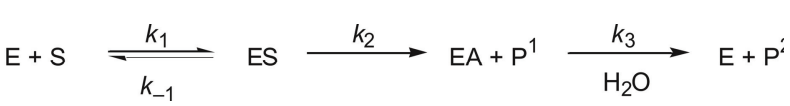

Scheme 1. 
Table 1. Inhibition constants of BChE by $(S)-N$-benzyl esters: the enzyme-inhibitor dissociation constant $K_{\mathrm{i}}$ and standard deviation was obtained from four experiments on average. The dissociation constant of enzyme-inhibitor complex was determined from Hunter-Downs plots. The value for SBzBzl was published previously ${ }^{15}$

\begin{tabular}{ccc}
\hline Inhibitor & $K_{\mathrm{m}} / \mathrm{mmol} \mathrm{dm}^{-3}$ & $K_{\mathrm{i}} / \mu \mathrm{mol} \mathrm{dm}$ \\
\hline SBuBzl & $0,19 \pm 0,01$ & $60,5 \pm 0,5$ \\
SPivBzl & $0,79 \pm 0,02$ & $12,3 \pm 0,2$ \\
SBzBzl $^{15}$ & $1,6 \pm 0,6$ & $3,3 \pm 0,4$ \\
\hline
\end{tabular}

$K_{\mathrm{m}}$ corresponds to $\left(k_{-1} / k_{1}+k_{2} / k_{1}\right)\left[k_{3} /\left(k_{2}+k_{3}\right)\right]$

activity, it was possible to determine enzyme-inhibitor dissociation constant $K_{\mathrm{i}}$. The enzyme-inhibitor dissociation constant $K_{\mathrm{i}}$ was calculated from equation $K_{\text {app }}=K_{\mathrm{i}}+\left(K_{\mathrm{a}} / K_{\mathrm{m}}\right) \cdot s$, where $K_{\text {app }}$ is the apparent enzymeinhibitor dissociation constant at a given substrate concentration $(s)$ and $K_{\mathrm{m}}$ is the Michaelis constant for the substrate. All $(S)$-esters acted as reversible inhibitors of the enzyme, Table 1. Only SAcBzl inhibited the enzyme when concentrations of $\mathrm{BzCh}$ were lower than 0.22 mmol dm ${ }^{-3}$, and activated the enzyme when the concentration of $\mathrm{BzCh}$ was higher, Figure 3. Therefore, it was not possible to determine the enzyme-inhibitor dissociation constant for that compound.

All other $(S)$-esters proved to be $\mu \mathrm{mol} \mathrm{dm}{ }^{-3}$ inhibitors, $(S)$-benzoate was the best inhibitor, closely followed by $(S)$-pivalate. $(S)$-butyrate had the lowest affinity toward BChE, Table 1 . The calculated values of $K_{\mathrm{m}}$ for the substrate used $(\mathrm{BzCh})$ obtained from kinetic studies with inhibitors can be compared with ones obtained from data without inhibitors $\left(K_{\mathrm{m}}(\mathrm{BzCh})=\right.$ $0.17 \pm 0.01) .{ }^{14}$ It can be concluded that SBuBzl competed with $\mathrm{BzCh}$ only in the active site while SPivBzl and especially SBzBzl competed with the substrate in the peripheral site as well.

To further explore the hydrolysis reaction of racemic $N$-benzyl quinuclidin-3-ol esters catalysed by $\mathrm{BChE}$, kinetic experiments were carried out to deter-

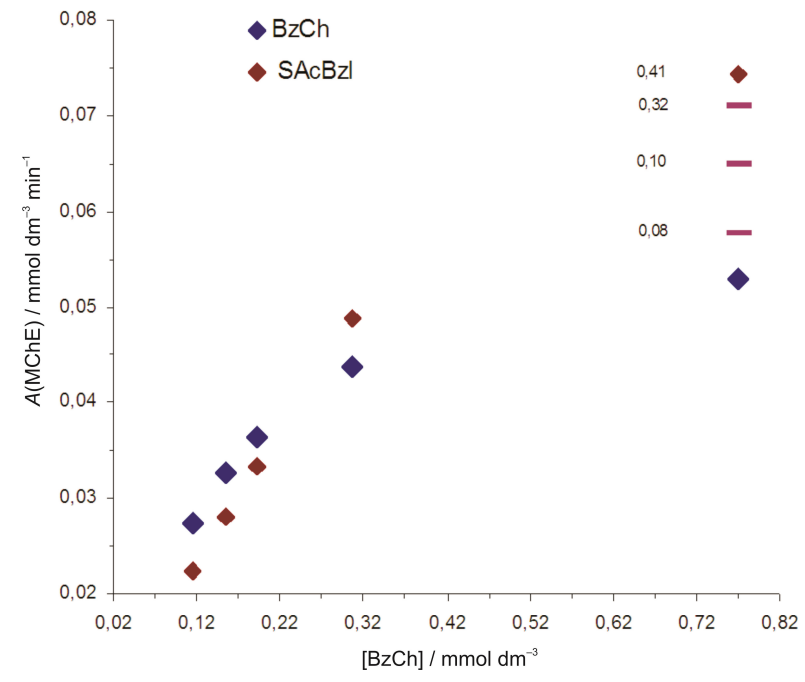

Figure 3. The kinetic study of inhibitory effectiveness of SAcBzl toward BChE in catalyzed hydrolyses of BzCh. Each data point represents the average value of three measurements. Concentrations of SAcBzl are expressed in $\mathrm{mmol} \mathrm{dm}^{-3}$.

mine the differences in rates of hydrolysis of pure $(R)$ enantiomers ( $2 \mathrm{mmol} \mathrm{dm}{ }^{-3}$ solution) and racemic mixtures which contained the same concentration of $(R)$ enantiomer ( $4 \mathrm{mmol} \mathrm{dm}{ }^{-3}$ solution of the racemate). The obtained values for enzymic activity are presented in Table 2.

All reactions of racemate mixtures were slower than the ones of pure $(R)$-enantiomers. The hydrolysis of RBuBzl was 2.0-fold, RPivBzl 2.7-fold faster, while that of RBzBzl was the fastest (5.1-fold) in comparison to the appropriate racemate. These data are in accordance with the measured inhibition constants for $(S)$ enantiomers, SBzBzl beeing the best inhibitor, followed by $(S)$-pivalate and $(S)$-butyrate. It is interesting that in the case of racemic AcBzl there was no effect of activation with present SAcBzl because RAcBzl was the substrate instead of BzCh, Figure 3., in the enzyme activity measurements. The hydrolysis of RAcBzl was 1.4-fold faster when $(S)$-enantiomer was not present, thus the inhibition of SAcBzl was the lowest in magnitude

Table 2. Activity of $\mathrm{BChE}(A)$ measured for racemic mixtures and $(R)$-enantiomers of all compounds: $4 \mathrm{mmol} \mathrm{dm}^{-3}$ solution of racemate and $2 \mathrm{mmol} \mathrm{dm}^{-3}$ solution of $(R)$-enantiomer. Each data point represents the average value of three measurements. $A_{R / \text { racemate }}$ corresponds to the ratio of $\mathrm{BChE}$ activity for $(R)$-enantiomer and racemate

\begin{tabular}{|c|c|c|c|c|}
\hline \multirow[b]{2}{*}{ Substrate } & \multicolumn{2}{|c|}{$A(\mathrm{BChE}) / \mathrm{mmol} \mathrm{dm}^{-3} \mathrm{~min}^{-1} \mathrm{mg}^{-1}$} & \multirow[b]{2}{*}{$A_{R / \text { racemate }}$} & \multirow[b]{2}{*}{$\begin{array}{c}\text { Inhibition by }(S) \text {-enantiomer / } \\
\%\end{array}$} \\
\hline & (R)-enantiomer & Racemate & & \\
\hline BuBzl & 0.993 & 0.502 & 2.0 & 50 \\
\hline AcBzl & 0.184 & 0.129 & 1.4 & 29 \\
\hline PivBzl & 0.252 & 0.094 & 2.7 & 63 \\
\hline BzBzl & 0.406 & 0.080 & 5.1 & 80 \\
\hline
\end{tabular}


among $(S)$-enantiomers. The BChE catalysed hydrolysis of RBzBzl was slower in case of $4 \mathrm{mmol} \mathrm{dm}^{-3}$ solution (Fig. 2.) than in case of $2 \mathrm{mmol} \mathrm{dm}^{-3}$ solution (Table 2.) indicating inhibition by substrate $(\mathrm{RBzBzl})$ when the higher substrate concentrations are present.

\section{CONCLUSION}

We have prepared racemic and enantiomerically pure esters of chiral quaternary $N$-benzyl quinuclidin-3-ol and butyric, acetic, pivalic and benzoic acid. Kinetic studies of BChE-catalyzed ester hydrolysis showed that the reaction proceeds in a stereoselective manner: $(R)$ enantiomers were hydrolyzed preferentially. On the other hand, $(S)$-enantiomers showed much higher affinity toward BChE and all were determined as $\mu \mathrm{mol} \mathrm{dm}{ }^{-3}$ inhibitors of the enzyme with the exception of the acetate derivative. It was revealed that there is a great influence of the acyl moiety both on the activity and stereoselectivity of the hydrolysis. The best substrates for the enzyme were butyrates which acyl group is the same as the one in butyrilcholine. Their acyl group fitted the best in the acyl binding site of the enzyme compared to other esters, resulting with the fastest reactions but, at the same time, with the loss of selectivity towards enantiomers. Smaller acetate group and bigger pivalate and benzoate could not realize a maximum possible interactions and the activity of the enzyme was lower. Among $(S)$-enantiomers, the differences in the activity of $\mathrm{BChE}$ were even more pronounced and partly related to their inhibitory properties. Effective inhibition of the enzyme indicates that there is a strong non-productive binding of $(S)$ enantiomers which can realize stabilizing contacts within the active site. ${ }^{14,16}$

Due to the satisfactory difference in the rates of hydrolysis of enantiomers, BChE can be used as a biocatalyst in preparations of optically pure quaternary quinuclidin-3-ols. $N$-benzyl group can be efficiently removed by catalytic transfer hydrogenation, ${ }^{20}$ thus regenerating chiral quinuclidin-3-ols, precursors for the synthesis of a range of pharmacologically interesting analogues. Consequently, kinetic resolution of racemic
$N$-benzyl quinuclidinium esters can be successfully achieved by the stereoselective hydrolysis catalysed with BChE.

Acknowledgements. This work was supported by the Ministry of Science, Education and Sports of the Republic of Croatia, Research Project No. 119-11913443121 .

\section{REFERENCES}

1. M. D. Mashkovsky, L. N. Yakhontov, M. E. Kaminka, and E. E. Mikhlina, Progress in Drug Research 27 (1983) 9-61.

2. A. Lucić, B. Radić, M. Peraica, M. Mesić, I. Primožič, and Z. Binenfeld, Arch. Toxicol. 71 (1997) 467-470.

3. V. Simeon-Rudolf, E. Reiner, M. Škrinjarić-Špoljar, B. Radić, A. Lucić, I. Primožič, and S. Tomić, Arch. Toxicol. 72 (1998) 289-295.

4. E. Reiner, M. Škrinjarić-Špoljar, S. Dunaj, V. Simeon-Rudolf, I. Primožič and S. Tomić, Chem.-Biol. Interact. 119-120 (1999) 173-181.

5. B. Ringdahl, R. S. Jope, and D. J. Jenden, Biochem. Pharmacol. 33 (1984) 2819-2822.

6. L. H. Sternbach and S. Kaiser, J. Am. Chem. Soc. 74 (1952) 2215-2218.

7. A, Kalir, E. Sali, and E. Shirin, Isr. J. Chem. 9 (1971) 267-268.

8. M. Rehavi, S. Maayani, and M. Sokolovsky, Life Sci. 21 (1977) 1293-1302.

9. D. C. Muchmore, Enantiomeric enrichment of (R,S)-3quinuclidinol US 5215918, 1993

10. K. Drauz and H. Waldmann, Eds., Enzyme Catalysis in Organic Synthesis: A Comprehensive Handbook, Second Edition, WileyVCH, Weinheim, 2002.

11. O. Lockridge, Pharmac. Ther. 47 (1990) 35-60.

12. M. Schelhaas, S. Glomsda, M. Hänsler, H.-D. Jakubke, and H. Waldmann, Angew. Chem. Int. Ed. 35 (1996) 106-109.

13. H. Sun, J. El Yazal, O. Lockridge, L. M. Schopfer, S. Brimijoin, and Y.-P. Pang, J. Biol. Chem. 276 (2001) 9330-9336.

14. I. Primožič, T. Hrenar, S. Tomić, and Z. Meić, J. Phys. Org. Chem. 58 (2002) 608-614.

15. I. Primožič, T. Hrenar, S. Tomić, and Z. Meić, Eur. J. Org. Chem. (2003) 295-301.

16. I. Primožič, T. Hrenar, S. Tomić, and Z. Meić, Croat. Chem. Acta 76 (2003) 93-99.

17. M. Schelhaas and H. Waldmann, Angew. Chem. Int. Ed. 35 (1996) 2056-2083.

18. A. Bosak, I. Primožič, M. Oršulić, S. Tomić, and V. SimeonRudolf, Croat. Chem. Acta. 78 (2005) 121-128.

19. D. M. Quinn, Chem. Rev. 87 (1987) 955-979.

20. S. Ram and L. D. Spicer, Tetrahedron Lett. 28 (1987) 515-516. 